\title{
HUBUNGAN PRESTASI BELAJAR AKIDAH AKHLAK TERHADAP PERILAKU SISWA MADRASH IBTIDAIYAH AL-MUJAHIDIN JAKARTA TIMUR
}

\author{
Asrori $^{1}$, Nofi Maria Krisnawati ${ }^{2}$, Salmani ${ }^{3}$ \\ ${ }^{1}$ Pendidikan Agama Islam Sekolah Tinggi Agama Islam (STAI) ALHIKMAH, Cilandak Jakarta Selatan \\ ${ }^{2,3}$ Pendidikan Guru Madrasah Ibtidaiyah Sekolah Tinggi Agama Islam (STAI) ALHIKMAH, Cilandak Jakarta \\ Selatan
}

Email: asrorisuparno@gmail.com ${ }^{1}$, nofimaria.73@gmail.com $^{2}$ min13jaktim.salma@gmail.com $^{3}$

\begin{abstract}
Abstrak
Penelitian ini bertujuan untuk mengetahui hubungan antara prestasi belajar Akidah Akhlak terhadap perilaku siswa kelas VI Madrasah Ibtidaiyah Al-Mujahidin Jakarta Timur. Sampel dalam penelitian ini sebanyak 35 siswa. Metode yang digunakan dalam penelitian adalah deskriptif korelatif, tehnik pengumpulan data menggunakan observasi, wawancara, dan penyebaran angket dengan menggunakan skala Likert dan rumus Product Moment correlation. Hasil penelitian di peroleh nilai coefisien correlation memperhatikan besarnya $r_{x y}(0,28)$ yang berkisar antara $(0,20-0,40)$ didapati antara $\mathrm{X}$ dan $\mathrm{Y}$ mempunyai Korelasi kecil dan hubungan rendah. Uji signifikasi korelasi Product Moment secara praktis, dikonsultasikan pada table $r$ Product Moment dapat dilihat $n=35$, taraf kesalahan $5 \%$ maka $r$ table $=0.334$ dan $r_{x y}(0,28)$ lebih kecil dari $r$ table $(0,334)$. Maka hipotesis alternative $(\mathrm{Ha})$ ditolak dan hipotesis nihil $(\mathrm{Ho})$ diterima. Sehingga dinyatakan bahwa korelasi antara prestasi belajar Akidah Akhlak terhadap perilaku Siswa dikategorikan lemah/rendah. Dengan melakukan pengujian secara signifikansi dapat disimpulkan bahwa t hitung (t0) $=1,67<$ dari t tabel $=$ 2,03. Jadi Ho diterima dan Ha ditolak, artinya tidak terdapat hubungan antara prestasi belajar Akidah Akhlak terhadap perilaku siswa-siswi kelas VI MI AI-Mujahidin Jakarta Timur. variabel prestasi belajar siswa kelas VI MI Al-Mujahidin Jakarta Timur memiliki korelasi terhadap variabel perilaku 0,07\%. Artinya korelasi tersebut korelasinya sedikit dan hubungan tidak terlihat . Namun hal ini juga dapat diartikan pengaruh prestasi belajar terhadap perilaku sebesar $0,07 \%$ dan sisanya $99,03 \%$ ditentukan faktor lain.
\end{abstract}

Kata kunci: Prestasi Belajar, Akidah Akhlak, Perilaku Siswa

\begin{abstract}
This study aimed to determine the relationship between learning achievement Akidah Akhlak to the behavior of class VI students of Madrasah Ibtidaiyah AI-Mujahidin, East Jakarta. The sample in this study were 35 students. The method used in the study is descriptive correlative, data collection techniques using observation, interviews, and questionnaires using a Likert scale and Product Moment correlation formula. The results obtained in the coefficient correlation value pay attention to the amount of rxy $(0.28)$ which ranges between $(0.20-0.40)$ found between $X$ and $Y$ have a small correlation and a low relationship. Practically testing the significance of Product Moment correlation, consulted on Product Moment table can be seen $n=35$, an error rate of $5 \%$, then $r$ table $=0.334$ and rxy (0.28) smaller than $r$ table (0.334). Then the alternative hypothesis $(\mathrm{Ha})$ is rejected and the null hypothesis $(\mathrm{Ho})$ is accepted. So it is stated that the correlation between the learning achievement of Akidah Akhlak to the behavior of students is categorized as weak/low. By testing significantly it can be concluded that $\mathrm{t}$ count $(\mathrm{t} 0)=1.67$ <rom t table $=2.03$. So $(\mathrm{Ho})$ is accepted and $(\mathrm{Ha})$ is rejected, meaning that there is no relationship between Akidah Akhlak learning achievement on the behavior of class VI students Madrasah Ibtidaiyah Al-Mujahidin, East Jakarta. the variable achievement of class VI students at Madrasah Ibtidaiyah Al-Mujahidin East Jakarta has a correlation to the behavioral variable of $0.07 \%$. This means the correlation is a little correlation and the relationship is not visible. But this can also be interpreted as the effect of learning achievement on behavior by $0.07 \%$ and the remaining $99.03 \%$ determined by other factors.
\end{abstract}


Keywords: Learning Achievement, Moral Creed, Student Behavior

\section{Pendahuluan}

Pendidikan sering diartikan sebagai usaha manusia untuk membina kepribadiannya sesuai dengan nilai-nilai di dalam masyarakat dan kebudayaan. Dalam perkembangannya, istilah pendidikan atau pedagogi berarti bimbingan atau pertolongan yang diberikan dengan sengaja oleh orang dewasa agar ia menjadi dewasa (Hasbullah,2012:34). Dalam undangundang RI. Nomor 20 tahun 2003 dijelaskan bahwa: pendidikan adalah usaha sadar dan terencana untuk mewujudkan suasana belajar dan proses pembelajaran agar peserta didik secara aktif mengembangkan potensi dirinya untuk memiliki kekuatan spiritual keamanan, pengendalian diri,kepribadian, kecerdasan, Akhlak mulia, serta keterampilan yang diperlukan dirinya, masyarakat, bangsa, dan negara (uud no. 20 tahun 2003).

Prestasi belajar tidak dapat dipisahkan dari perbuatan belajar, karena belajar merupakan suatu proses, sedangkan prestasi belajar adalah hasil dari proses pembelajaran tersebut. Tujuan belajar dapat dikatakan berhasil jika terjadi perubahan dalam diri siswa, namun tidak semua perubahan perilaku dapat dikatakan belajar karena perubahan tingkah laku akibat belajar memiliki ciri-ciri perwujudan yang khas (Eva Nauli Thaib dalam Muhibbin Syah, 2000:116).

Marsun dan Martaniah dalam Sia Tjundjing berpendapat bahwa prestasi

belajar merupakan hasil kegiatan belajar, yaitu sejauh mana peserta didik menguasai bahan pelajaran yang diajarkan, yang diikuti oleh munculnya perasaan puas bahwa ia telah melakukan sesuatu dengan baik (Poerwati, 2010). Hal ini berarti prestasi belajar hanya bisa diketahui jika telah dilakukan penilaian terhadap hasil belajar siswa. (Sia Tjundjing: 2001).

Akidah Akhlak merupakan salah satu sub mata pelajaran yang di ajarakan di Madrasah Ibtidayah (sederajat denan Sekolah Dasar) yang terdapat dalam kurikulum nasional. Tujuan dari pembelajaran tersebut diantara untuk menanamkan Akidah Akhlak siswa guna mencapai perilaku yang baik sehingga dapat di aplikasikan dalam kehidupan sehari hari. Secara substansial mata pelajaran Akidah-Akhlak memiliki kontribusi dalam memberikan motivasi kepada peserta didik untuk mempraktekkan perilaku yang baik, sopan dan satun dalam kehidupan sehari-hari sebagai manifestasi dari keimanannya kepada Allah, Malaikat-malaikat-Nya, Kitab-kitab-Nya, Rasul-rasul-Nya, Hari Akhir, serta Qadha dan Qadar (Rukun Iman). Meskipun demikian pada tataran prakteknya masih banyak didapati kejaadian-kejadian menyimpang, seperti kurangnya tata krama dan sopan santun anak terhadap orang tua maupun guru, kenakalan dan kekacauan yang sering dilakukan oleh anak-anak sekolah.

Perilaku dalam bahasa Inggris disebut dengan "behavior" yang berarti kelakuan, tindak-tanduk jalan. Perilaku juga terdiri dari dua kata peri dan laku, peri mengandung makna sekeliling, dekat, melingkupi. sedang laku mengandung makna tingkah laku, perbuatan, tindak tanduk. Kata perilaku mempunyai pengertian yang sangat luas, yaitu tidak hanya mencakup kegiatan yang motorik saja, seperti; berjalan, berlari-lari, berolah raga, bergerak dan lain-lain. Akan tetapi juga membahas macam-macam fungsi seperti: melihat, mendengar, mengingat, berpikir, fantasi, pengenalan kembali, penampilan emosi dalam bentuk tangis atau senyum dan sebagainya (Salahuddin,2001: 55).

Memiliki anak-anak yang berperilaku baik adalah harapan bagi setiap orang tua, dan tentunya menjadi cita-cita terbesar bagi guru dalam melaksanakan pembelajaran di sekolah. Namun harapan dan cita-cita tersebut berbenturan dengan arus globalisasi, informasi yang tak terbendung dan penurunan perilaku yang tidak hanya tampak di kota-kota saja, tapi juga tampak di pelosok sudut desa. Merespon fenomena tersebut, pemerintah dengan misi revolusi mental/karakter bangsa memberikan porsi lebih besar dibandingkan pendidikan yang mengajarkan pengetahuan. 70\% untuk Sekolah Dasar dan 60\% untuk sekolah Menengah Pertama. 
Adapun kesinergisan antara prestasi dengan perilaku seperti apa yang telah ditemukan Fauzi (2006:78), bahwa terdapat hubungan antara prestasi Akidah Akhlak dengan perilaku keberagaman siswa. Hipotesi tersebut dikuatkan dengan hasil penelitian yang dilakukan oleh Aminah (2014) dimana hasil pengujian hipotesis menunjukkan terdapat hubungan yang signifikan antara pengaruh Hasil Belajar Akidah Akhlak terhadap Tingkah Laku Siswa MI Ar-Rahmah Tugu Cimanggis Depok dengan T hitung sebesar 4,737 dan nilai $T$ tabel dengan $\alpha=0,05$ dan $\mathrm{dk}=30-2=28$ di peroleh nilai $T$ tabel sebesar 1,701 . Karena $T$ hitung $>\mathrm{T}$ tabel maka dapat di simpulkan terdapat korelasi positif yang signifikan antara pengaruh Hasil Belajar Akidah Akhlak terhadap Tingkah Laku Siswa MI Ar-Rahmah Tugu Cimanggis.

Oleh sebab itu peneliti merasa tertarik dan ingin mengkaji lebih jauh hubungan antara prestasi belajar Akidah Akhlak dengan perilaku siswa. Peneliti mengadakan penelitian di Ml Al-Mujahidin Jakarta Timur, sebab di MI Al-Mujahidin masih terlihat beberapa siswa yang berprilaku kurang baik, seperti terjadinya perselisihan antar siswa, berkata kasar, berkata tidak sopan (jorok) dan sebagainya. Hal ini menarik bagi penulis untuk mengadakan penelitian dengan judul "Hubungan prestasi Belajar Akidah Akhlak dengan Akhlak siswa MI Al-Mujahidin Jakarta Timur".

Identitas Masalah dalam penelitian ini adalah siswa-siswi kelas V MI Al-Mujahidin kelurahan Batu Ampar Kecamatan Karamat Jati Jakarta Timur. Berdasarkan latar belakang masalah diatas, dapat diidentifikasi beberapa masalah sebagai berikut: 1). Apakah terdapat hubungan antara prestasi belajar Akidah Akhlak dengan perilaku siswa MI Al-Mujahidin. 2). Apakah terdapat hubungan antara prestasi belajar Akidah Akhlak terhadap etika Siswa MI Al-Mujahidin dengan orang tua, guru dan teman 3). Apakah terdapat hubungan antara pendidikan di lingkungan keluarga dengan Akhlak Siswa MI Al-Mujahidin dan 4). Apakah terdapat hubungan antara lingungan sekolah terhadap Akhlak siswa-siswi di Ml AlMujahidin.

Agar penelitian ini mampu menghasilkan gambaran yang jelas, terarah dan tidak terlalu luas jangkaunnya maka diperlukan pembatasan masalah. Adapun pembatasan dalam penelitian ini adalah: 1). Perilaku siswa yang dimaksud adalah tingkah laku siswa-siswi MI Al-Mujahidin dalam berinteraksi dengan orang tua, guru, dan teman di lingkungan sekolah. 2). Mata pelajaran Akidah Akhlak yang dimaksud adalah salah satu mata pelajaran yang di berikan pada tingkat pendidikan MI mulai dari kelas satu sampai kelas VI. 3). Prestasi belajar 'Akidah Akhlak yang di maksud adalah nilai raport

Setelah mengetahui pembatasan masalah, maka peneliti berusaha untuk merumuskan permasalahan sebagai berikut 1). Bagaimana perilaku siswa MI Al Mujahidin? 2). Adakah hubungan prestasi belajar Akidah Akhlak dengan perilaku siswa MI AlMujahidin?

Adapun tujuan yang ingin dicapai didalam penelitian ini adalah 1). Untuk memperoleh gambaran yang jelas tentang prestasi belajar Akidah Akhlak siswa Madrasah Ibtidaiyah AlMujahidin. 2). Untuk memperoleh gambaran tentang perilaku siswa sehari-hari. 3). Untuk mengetahui hubungan antara mata pelajaran Akidah Akhlak terhadap Akhlak siswa

\section{Metode}

Dalam penelitian ini, peneliti menggunakan total sampel yaitu seluruh siswa kelas VI MI Al-Mujahidin Jakarta Timur yang berjumlah 35 siswa. Teknik pengumpulan data yang peneliti gunakan adalah (1). Observasi, menurut Sutrisno Hadi (1986) yang dikutip oleh Sugiyono (2017: 45) dalam buku Metode Penelitian Pendidikan merupakan suatu proses yang kompleks, suatu proses yang tersusun dari berbagai proses biologis dan psikologis. Dua diantaranya yang terpenting adalah proses-proses pengamatan dan ingatan. Teknik ini dipakai untuk melihat secara langsung bagaimana siswa kelas VI dalam bersikap maupun berbicara dengan warga sekolah dalam hal ini guru dan teman-teman, serta melihat proses kegiatan belajar dan mengajar di kelas tersebut. Dalam hal ini observasi yang dilakukan peneliti adalah observasi partisipasi pasif artinya peneliti hanya datang ditempat kegiatan siswa yang diamati tetapi tidak ikut terlibat dalam kegiatan.(2). Wawancara adalah 
merupakan pertemuan dua orang untuk bertukar informasi dan ide melalui Tanya jawab, sehingga dapat di kontruksikan makna dalam suatu topik tertentu. Dalam wawancara peneliti menggunakan teknik wawancara tidak terstruktur adalah wawancara bebas dimana peneliti tidak menggunakan pedoman wawancara yang tidak tersusun secara sistematis dan lengkap untuk mengumpulkan datanya. Pada penelitian ini peneliti bertanya secara langsung dengan kepala MI Al-Mujahidin tentang hal-hal yang berkaitan dengan siswa maupun guru mata pelajaran Akidah Akhlak dan wawancara dengan guru mata pelajaran Akidah Akhlak itu sendiri tentang kondisi siswa ketika proses pembelajaran maupun metode yang digunakan ketika KBM berlangsung. (3). Kuesioner (angket) merupakan teknik pengumpulan data yang dilakukan dengan cara memberi seperangkat pertanyaan atau pernyataan terulis kepada responden untuk di jawabnya (Sugiyono,2007:194).Tujuan penyebaran angket adalah untuk mendapatkan jawaban atas pertanyaan-pertanyaan yang berhubungan dengan Akhlak Mahmudah dan Akhlak Madhmumah. Angket yang digunakan adalah angket terstruktur yaitu angket yang disajikan dalam bentuk sedemikian rupa sehingga responden diminta untuk memilikh satu jawaban yang sesuai dengan karakteristik dirinya.

Instumen yang peneliti gunakan untuk mengukur variabel $X$ adalah prestasi belajar siswa yang di ukur/diambil dari nilai raport sedangkan instrumen untuk mengukur variable $Y$ adalah perilaku siswa dengan menggunakan kuesioner yang harus di isi siswa, dengan jumlah pertanyaan yang terdiri dari 18 pertanyaan tentang perilaku yang baik dan 18 pertanyaan tentang perilaku yang buruk.

Sebelum digunakan untuk alat ukur dalam penelitian, sebelumnya kuesioner diuji validitas dan reabilitas. Instrumen yang valid berarti alat ukur yang digunakan untuk mendapatkan data (mengukur) itu valid. Valid berarti instrumen tersebut dapat digunakan untuk mengukur apa yang seharusnya di ukur. Instrumen yang realibel adalah instrumen yang apabila digunakan bebebrapa kali untuk mnegukur objek yang sama, akan mengahasilkan data yang sama (Sugiyono,2012:173). Peneliti menggunakan 25 responden lain untuk mengukur uji Instrumen perilaku. Rentang skor teoritik antara 93 sampai dengan 125. Valitidas butir instrumen ditentukan dengan membandingkan antara besaran $r_{x y}$ yang diperoleh dengan harga kritis $r$ Pearson's Product Moment pada $\mathrm{N}=25$. Berdasarkan hasil perhitungan validitas instrumen Akhlak diketahui dari 36 butir pernyataan semuanya valid karena nilai korelasi tiap butir lebih besar dari 0,396 . Jumlah butir yang valid dan digunakan sebagai alat pengambil data penelitian tetap sebanyak 36 butir pernyataan. Dengan demikian, rentang skor teoritik antara 93 sampai dengan 125.

Berdasarkan item-Total Statistics Corrected Item-Total Correlation dapat dilihat bahwa item 1 sampai item 36 valid, dengan bukti nilai $r$-Hitung > r-Tabel, maka item pertanyaan itu dinyatakan valid.

Perhitungan Reliabilitas dengan menggunakan rumus Alpha Cronbach.. Penghitungan reliabilitas instrumen Akhlak sebanyak 36 butir menghasilkan rii=0,943. Di dapat nilai Cronbach's Alpha 0,925. Dari out put maka di simpulkan bahwa alat ukur dalam penelitian ini sudah reliable karna lebih besar dari 0,60.

Jawaban setiap item instrumen menggunakan Skala Likert mempunyai gradasi dari sangat positif sampai sangat negatif, yang dapat berupa kata-kata serta untuk keperluan analisis kuantitatif, maka jawaban itu dapat di beri skor, yaitu:(Sugiono,2012:134)

Tabel 1. Skor Untuk Statemen Positif Dan Negatif Untuk Perilaku Kelas VI Mi Al-Mujahidin Jakarta Timur

\begin{tabular}{llcc}
\hline No. & \multicolumn{1}{c}{ Alternatif Jawaban } & \multicolumn{2}{c}{ Skor Item Pernyataan } \\
\cline { 1 - 3 } \cline { 3 - 4 } 1 & Sangat Setuju /Selalu & $(+)$ & $(-)$ \\
2 & Setuju /Sering & 5 & 1 \\
3 & Kurang Setuju /Kadang -kadang & 4 & 2 \\
\hline
\end{tabular}




\begin{tabular}{llll}
\hline 4 & Tidak Setuju / Jarang & 2 & 4 \\
5 & Sangat Tidak Setuju/Tidak Pernah & 1 & 5 \\
\hline
\end{tabular}

Setelah data terkumpul, langkah berikutnya adalah pengolahan data. Dalam pengolahan data beberapa hal yang harus dilakukan adalah: Editing yaitu data yang masuk perlu diperiksa apakah terdapat kekeliruan dalam pengisian, barangkali ada yang tidak lengkap, palsu, tidak sesuai dan sebagainya. Coding yaitu setelah penyuntingan diselesaikan, kegiatan selanjutnya yang perlu dilakukan adalah pemberian kode (pengkodean). karena angket yang di buat adalah angket tertutup maka kategori jawaban dilakukan berdasarkan skala Likert. Tabulasi yaitu Jawaban-jawaban yang serupa dikelompokkan dengan cara yang teliti dan teratur, kemudian dihitung dan di jumlah berapa banyak items yang termasuk dalam satu kategori (Mahyudin,2014:53).

Untuk menghitung kuat-lemah atau tinggi-rendahnya antar dua variabel yang sedang diteliti dapat diketahui dengan melihat besar kecilnya angka indeks korelasi, yang pada teknik korelasi Product Moment di beri lambang " $r$ " (sering disebut "r" Product Moment). Apabila variabel pertama di beri lambang $X$ dan variabel kedua di beri lambang $Y$ maka indeks korelasinya dinyatakan dengan lambang $r_{x y}$ (Sugiyono,2014:255).

$r_{x y}=\frac{N \sum x Y-\left(\sum x\right)\left(\sum Y\right)}{\sqrt{\left[N \sum x^{2}-\left(\sum x\right)^{2}\right]\left[N \sum_{Y}^{2}-\left(\sum Y\right)^{2}\right]}}$

\section{Keterangan:}

$r_{\mathrm{xy}} \quad=$ Angka indeks korelasi " $r$ " Product Moment

$\mathrm{N}=$ Number of Cases

$\Sigma X Y=$ Jumlah hasil perkalian antara skor $X$ dan skor $Y$

$\sum X=$ Jumlah seluruh skor $X$

$\sum Y=$ Jumlah seluruh skor $Y$

Dalam memberikan interpretasi secara sederhana terhadap angka indeks korelasi " $r$ " Product Moment $\left(r_{x y}\right)$, menurut J.P Guilford dalam buku Anas Sudijono (2007:92), pengantar Statistik Pendidikan pada umumnya dipergunakan pedoman sebagai berikut:

Tabel2. Kriteria Keeratan

\begin{tabular}{ccl}
\hline No & Kisaran Koefisien $(\%)$ & \multicolumn{1}{c}{ Tingkat Keeratan } \\
\hline 1 & $0,00-0,20$ & Korelasi sedikit dan hubungan tidak terlihat \\
2 & $0,20-0,40$ & Korelasi kecil dan hubungan rendah \\
3 & $0,40-0,70$ & Korelasi sedang dan hubungan nyata \\
4 & $0,70-0,90$ & Korelasi tinggi dan hubungan kuat \\
5 & $0,90-1,00$ & Korelasi sangat tinggi dan hubungan sangat kuat
\end{tabular}

Untuk menguji kebenaran hipotesis antara kepuasan prestasi dengan Akhlak, maka dilakukan uji hipotesis menggunakan alat analisis (Sugiono,2007).

$$
T O=\frac{r \sqrt{(\mathrm{n}-2)}}{\sqrt{\left(1-\mathrm{r}^{2}\right)}}
$$

Keterangan:

TO

$r_{x y}=$ Angka indeks korelasi "r" Product Moment

$\mathrm{N} \quad=$ Number of Cases

Dengan pengujian hipotesis sebagai berikut: 
$\mathrm{HO}: \mathrm{r}=0$ (tidak ada hubungan antara prestasi belajar Akidah Akhlak terhadap perilaku siswa siswi MI Al-Mujahidin Jakarta Timur)

$\mathrm{H}_{\mathrm{a}}: \mathrm{r} \neq 0$ (ada hubungan antara prestasi belajar Akidah Akhlak terhadap perilaku siswa siswi MI Al-Mujahidin Jakarta Timur)

Jika hasil analisis diperoleh $t_{0}>t_{\text {tabel }}$ maka $\mathrm{HO}$ ditolak atau $\mathrm{H}_{\mathrm{a}}$ diterima, artinya ada hubungan yang signifikan antara prestasi belajar Akidah Akhlak terhadap Perilaku siswa siswi Ml Al-Mujahidin Jakarta Timur. Akan tetapi, jika $t_{0}<t_{\text {tabel }}$ maka $\mathrm{HO}$ diterima, artinya tidak ada hubungan yang signifikan antara antara prestasi belajar Akidah Akhlak terhadap Perilaku siswa MI Al-Mujahidin Jakarta Timur.

Untuk mengetahui kontribusi variabel $\mathrm{X}$ terhadap variabel $\mathrm{Y}$ peneliti menggunakan rumus perhitungan koefisiensi determinasi $(\mathrm{KD})$ sebagai berikut :

$K D=r^{2} X 100$

Keterangan :

$\mathrm{KD}=$ Koefisiensi Determinasi

$r_{x}=$ Angka indeks korelasi " $r$ " Product Moment

\section{Hasil dan Pembahasan}

Penelitian ini bertujuan untuk mengetahui korelasi antara konsep diri dengan motivasi belajar pada siswa kelas XI BKP di SMK Negeri 2 Salatiga. Hasil uji korelasi dapat diketahui pada Tabel 1. Pada Tabel 1 terlihat bahwa ada hubungan konsep diri dengan motivasi belajar.

Tabel 1. Hasil Uji Korelasi Konsep Diri dengan Motivasi Belajar

\begin{tabular}{lllll}
\hline \multicolumn{4}{c}{ Correlations } \\
\hline & & & \\
\hline & & & \\
Kenda KONSEP & Correlation Coefficient & 1.000 & \\
II's & DIRI & Sig. (2-tailed) &. & $.883^{* *}$ \\
tau_b & $\mathrm{N}$ & 72 & .000 \\
& MOTIVASI & Correlation Coefficient & $.883^{* *}$ & 72 \\
& BELAJAR & Sig. (2-tailed) & .000 & 1.000 \\
& $\mathrm{~N}$ & 72 &. \\
\hline
\end{tabular}

**. Correlation is significant at the 0.01 level (2-tailed).

Berdasarkan hasil uji korelasi diatas maka diketahui nilai $r_{x y}=0,883$ dengan koefesien signifikansi $0,000 \leq 0,01$, dengan demikian dapat ditarik kesimpulan bahwa ada hubungan yang signifikan antara Konsep Diri dengan Motivasi Belajar siswa kelas XI BKP di SMK Negeri 2 Salatiga. Artinya semakin tinggi konsep diri peserta didik, maka semakin tinggi pula tingkat motivasi belajar peserta didik. Menurut Sugiyono (2011) koefisien korelasi 0,883 menunjukkan tingkat hubungan yaitu antara 0,80 - 1,000 yang artinya sangat kuat. 


\section{Hubungan konsep diri dengan motivasi belajar}

Menurut Hurlock (1980), konsep diri diartikan sebagai persepsi, keyakinan, perasaan, atau sikap sesorang tentang dirinya sendiri, kualitas penyikapan individu tentang dirinya sendiri dan suatu sistem pemaknaan individu tentang dirinya sendiri dan pandangan orang lain tentang dirinya. Menutut Ghufron dan Rini Risnawita (2010), kosep diri adalah penentu pengharapan individu. Konsep diri merupakan seperangkat harapan dan penilaian perilaku terhadap harapan tersebut, sehingga bila sikap dan pandangan negatif terhadap kemampuan diri menyebabkan individu menetapkan titik harapan yang rendah. Motivasi belajar akan mendorong siswa untuk mengikuti kegiatan belajar dan mengajar di sekolah dengan baik.

Motivasi belajar yang tinggi akan mendorong siswa untuk belajar dengan sunguhsungguh, namun sebaliknya jika motivasi belajar siswa rendah maka siswa tersebut tidak akan belajar dengan sunguh-sungguh. Motivasi erat kaitannya dengan perilaku siswa. Bagaimana perilaku siswa dalam belajar akan dipengaruhi oleh motivasi belajar. Dengan demikian siswa yang mempunyai motivasi belajar yang tinggi akan cenderung berperilaku positif dalam belajar selalu mengerjakan tugas, memperhatikan guru.

Selanjutnya Calhoun \& Acocella (1995), mengartikan konsep diri sebagai gambaran mental individu yang terdiri dari pengetahuan tentang diri sendiri, pengharapan bagi diri sendiri, dan penilaian terhadap diri sendiri. Selain itu ahli ini juga menyatakan bahwa konsep diri merupakan hal terpenting bagi kehidupan individu, Karena konsep diri menentukan bagaimana individu bertindak dalam berbagai stimulasi, salah satunya situasi saat belajar, siswa yang memiliki konsep diri bagus tentu akan memiliki persepsi yang bagus tentang kegiatan dan proses belajar yang ditandai dengan belajar tekun, mengerjakan tugas, namun bila siswa yang memiliki konsep diri yang rendah tentu meiliki persepsi negatif tentang belajar, hal ini ditandai dengan sikap membolos, tidak mengerjakan tugas dan perilaku lainnya pada diri siswa yang negatif dalam proses belajar.

Oleh karena itu konsep diri dianggap sebagai pemegang peran kunci dalam pengintegrasian kepribadian individu didalam memotivasu tingkah laku, terutama saat belajar. Selain itu banyak psikolog yang beranggapan bahwa yang memegang peran penting di dalam integrasi kepribadian, di dalam motivasi tingkah laku, didalam mencapai kesehatan mental, semua ini berasal dari konsep diri. Selain itu sejumlah ahli psikologi dan pendidikan juga berkeyakinan bahwa konsep diri dan prestasi belajar mempunyai hubungan yang erat.

Nylor dalam Desmita (2009) misalnya, mengemukakan bahwa banyak pendidikan yang membuktikan hubungan positif yang kuat antara konsep diri positif dengan prestasi belajar di sekolah. Siswa yang memiliki konsep diri positif memperlihatkan prestasi yang baik di sekolah, atau siswa yang berprestasi tinggi disekolah memiliki penilaian diri yang tinggi, serta menunjukan hubungan antarpribadi yang positif pula. Motivasi belajar dapat timbul karena faktor intrinsik, berupa hasrat dan keinginan berhasil dan dorongan kebutuhan belajar, harapan akan cita-cita. Sedangkan faktor ekstrinsik berupa adanya penghargaan, lingkungan belajar yang kondusif, dan kegiatan belajar yang menarik. Motivasi dalam belajar adalah motivasi yang tersebut melahirkan prestasi belajar. Para pendidik telah sadar akan dampak self-concept dan self esteem terhadap tingkah laku anak di dalam kelas dan terhadap prestasinya.

\section{Pembahasan}

Hasil penelitian menunjukkan ada hubungan antara konsep diri dengan motivasi belajar siswa kelas XI BKP di SMK Negeri 2 Salatiga mempunyai koefisien korelasi $r=0,883$ dengan koefesien signifikansi $p=0,000 \leq 0,01$, artinya ada hubungan signifikan antara Konsep Diri dengan Motivasi Belajar siswa kelas XI BKP di SMK Negeri 2 Salatiga. Artinya 
semakin tinggi konsep diri peserta didik, maka semakin tinggi pula tingkat motivasi belajar peserta didik.

Hasil penelitian ini mendukung penelitian yang dilakukan oleh : Lutfi (2009) tentang Hubungan Konsep Diri Dengan Motivasi Belajar pada Mahasantrimahad Sunan Ampel AlAly UIN Maulana Malik Ibrahim Malang, hasil penelitian menunjukkan bahwa terdapat hubungan yang signifikan antara konsep diri dengan motivasi belajar dengan kontribusi hubungan sebesar 46,3\%. Sedangkan hasil penelitian Sahputra (2009) tentang Hubungan Konsep Diri Dengan Motivasi belajar pada Mahasiswa SI Keperawatan Semester III Kelas Ekstensi PPSIK FK USU Medan, menunjukkan bahwa antara konsep diri dengan motivasi belajar terdapat hubungan yang bermakna dengan $r=-0,384$ dan $p=0,006$. Sedangkan hasil penelitian Aditi (2012) tentang Hubungan Konsep Diri Dengan Motivasi Belajar Siswa Kelas XI Di SMA Negeri 7 Padang Tahun 2012, menunjukkan bahwa konsep diri yang dimiliki siswa kelas XI di SMA Negeri 7 Padang adalah lebih dari separuh siswa memiliki konsep diri positif $(55,7 \%)$ dan sebagian besar siswa memiliki motivasi belajar yang tinggi $(88,1 \%)$. Disimpulkan bahwa terdapat hubungan yang bermakna antara konsep diri dengan motivasi belajar siswa dengan nilai $p=0,000(p<0,05)$.

Menurut Uno (2006) Motivasi dan belajar merupakan dua hal yang saling mempengaruhi. Motivasi belajar dapat timbul karena faktor intrinsik, berupa hasrat dan keinginan berhasil dan dorongan kebutuhan belajar, harapan akan cita-cita. Sedangkan faktor ekstrinsiknya adalah adanya penghargaan, lingkungan belajar yang kondusif, dan kegiatan belajar yang menarik.

Hasil penelitian ini mendukung teori yang dikembangkan oleh Nylor dalam Desmita (2009) misalnya, mengemukakan bahwa banyak pendidikan yang membuktikan hubungan positif yang kuat antara konsep diri positif dengan prestasi belajar di sekolah. Siswa yang memiliki konsep diri positif memperlihatkan prestasi yang baik di sekolah, atau siswa yang berprestasi tinggi disekolah memiliki penilaian diri yang tinggi, serta menunjukan hubungan antarpribadi yang positif pula. Motivasi belajar dapat timbul karena faktor intrinsik, berupa hasrat dan keinginan berhasil dan dorongan kebutuhan belajar, harapan akan cita-cita. Sedangkan faktor ekstrinsik berupa adanya penghargaan, lingkungan belajar yang kondusif, dan kegiatan belajar yang menarik.Motivasi dalam belajar adalah motivasi yang tersebut melahirkan prestasi belajar. Para pendidik telah sadar akan dampak self-concept dan self esteem terhadap tingkah laku anak di dalam kelas dan terhadap prestasinya.

\section{Simpulan dan Saran}

Berdasarkan hasil penelitian diatas dapat disimpulkan bahwa (1) terdapat korelasi antara variabel $\mathrm{X}$ dan $\mathrm{Y}$ dan tidak bertanda negatif berarti diantara kedua variabel tersebut terdapat korelasi positif (korelasi yang berjalan searah). (2) Besarnya rxy (yaitu =0,28) yang berkisar antara $(0,20-0,40)$ berarti antara $X$ dan $Y$ mempunyai Korelasi kecil dan hubungan rendah. (3) (4) Uji signifikasi korelasi Product Moment secara praktis, dikonsultasikan pada table $r$ Product Moment dapat dilihat $n=35$, taraf kesalahan $5 \%$ maka harga $r$ table $=0.334$ dan $r x y(0,28)$ lebih kecil dari $r$ table $(0,334)$. Dengan demikian ternyata rxy lebih kecil dari $r$ table, maka hipotesis alternatif(Ha) ditolak dan hipotesis nihil(Ho) diterima.Dengan demikian dapat dinyatakan bahwa korelasi antara prestasi belajar Akidah Akhlak terhadap Akhlak dikategorikan lemah/rendah.Berdasarkan hasil uji hipotesis yang kedua didapatkan hasil bahwa $t$ hitung $(\mathrm{t} 0)=1,67<$ dari $\mathrm{t}$ tabel $=2,03$. Jadi $\mathrm{HO}$ diterima dan $\mathrm{Ha}$ ditolak, artinya tidak terdapat hubungan antara prestasi belajar Akidah Akhlak terhadap perilaku siswa kelas VI MI Al-Mujahidin Jakarta Timur.(5) Korelasi variabel $X$ dan variabel $Y$ sebesar $0,07 \%$. Artinya korelasi tersebut sedikit dan hubungan tidak terlihat . Namun hal ini juga dapat diartikan pengaruh prestasi belajar terhadap perilaku $=0,07 \%$ dan sisanya $99,03 \%$ ditentukan faktor lain. 
Berdasarkan hasil penelitian dapat diajukan saran sebagai berikut :(1). Guru memiliki peranan penting sebagai salah satu komponen yang turut menuntut keberhasilan pendidikan. Oleh karena itu guru dalam kegiatan mengajar harus dapat menemukan metode apa yang tepat untuk diterapkan dalam setiap kegiatan belajar mengajar. Dengan demilkian diharapkan dalam penyampaian materi pelajaran Akidah Akhlak pada umur tingkat Madrasah Ibtidaiyah terutama kelas bawah bisa melalui cerita-cerita Nabi dan Rosul dan para sahabat Nabi yang memiliki sifat terpuji dan menjauhi sifat tercela, serta keistimewaan orang dan memiliki sifat terpuji dan kerugian orang memiliki sifat tercela.Menumbuhkan suasana kompetensi dalam kelas yangbertujuan untuk mendorong siswa mencapai prestaasi belajar yang baik. Mengajar sekaligus mendidik agar tujuan pembelajaran Akidah Akhlak berhasil dan terlihat dalam tingkah laku anak sehari-hari baik di sekolah maupun di rumah. (2). Orang tua merupakan madrasah pertama untuk anak, Namun demikian setelah anak sudah mulai memasuki dunia pendidikan peran orang tua tidak boleh berkurang dalam pengawasan baik ketika anak belajar atau bersosialisai di lingkungan sekitar orang tua harus: Ikut serta dalam memberikan motivasi kepada anak selalu memberikan pengawasan dan pendampingan dalam kegiatan belajar anak. Orang tua bekerjasama (berkomunikasi) dengan guru tentang perkembangan anak disekolah.

\section{Daftar Pustaka}

Agung, A.A Gede, 2014. Metodologi Penelitian Pendidikan. Yogyakarta: Aditya Media Publishing.

Agus, E.S, 2007. Aplikasi Statistik dengan SPSS untuk pemula, Jakarta: Prestasi pustaka publisher.

Ahmad,S. 2016. Teori Belajar dan Pembelajaran di Sekolah Dasar, Jakarta: Prenada Media Group.

Anas,S. 2012. Pengantar statistik Pendidikan, Jakarta: Rajagrafindo Persada.

Eva, NT. Hubungan Antara Prestasi Belajar Dengan Kecerdasan Emosional. Jurnal IImiah DIDAKTIKA, Vol. 8, No. 2.

Mahfudh, S. 1991. Pengantar Psikologi Umum, Surabaya: Sinar Wijaya.

Mahyudin, 2004. Modul Kuliah Metode Penelitian Pendidikan, Jakarta:Pustaka Hikmah.M. Alisuf.S, 2006. Pengantar Psikologi Umum \& Perkembangan, Jakarta: Pedoman IImu

Jaya.Muhibbin Syah. 2000. Psikologi Pendidikan dengan Suatu Pendekatan Baru, Bandung: PT. Remaja Rosdakary

Poerwati, Tjahjaning. 2010. Pengaruh Perilaku Belajar Dan Motivasi Terhadap Prestasi Akademik Mahasiswa Akuntansi Di Universitas STIKUBANK (UNISBANK) Semarang. Jurnal Fakultas Ekonomi Universitas STIKUBANK. Vol 8, No 16

Rafiqah, M. Yumansyah, dan Mayasari, S. 2013. Pengaruh Motivasi Belajar Siswa Terhadap Prestasi Belajar Siswa. Jurnal Bimbingan Konseling. Vol. 2, No. 2

Sugiyono, 2014. Metode Penelitian Pendidikan (Pendekatan Kuantitatif, Kualitatif, dan R \& D). Bandung: Alfabeta. 
Sugiyono, 2007. Metodologi Penelitian Pendidikan, Bandung: Alfabeta Bandung

Tim Pengembang Pedoman Bahasa, 2016. Pedoman Umum Bahasa Indonesia Yang Disempurnahkan, Jakarta: Badang Pengembangan dan Pembinaan Bahasa Kementerian Pendidikan dan Kebudayaan.

Wibowo A. 2012. Pendidikan Karakter: Strategi Membangun Karakter Bangsa Berperadaban, Yogyakarta: Pustaka Pelajar.

Wulandari. 2014. Pengaruh Motivasi Belajar, Perilaku Belajar dan Model Pembelajaran Konstruktivisme Terhadap Prestasi Belajar Mahasiswa Kelas Reguler Fakultas Ekonomi dan Bisnis UIN Syarif Hidayatullah Jakarta. Jurnal Bisnis dan Manajemen. Vol. 4 No. 1, April 2014. 